\title{
SOCIAL DIMENSIONS OF POLITICAL RISK - SDPR: CONCEPT AND INDEX FOR RISK IMPACT ON SOCIETY
}

\author{
Rada Kodjabasheva ${ }^{1}$ \\ e-mail: radakodjabasheva@gmail.com
}

\begin{abstract}
Political risk concerns the profits and investment plans of international business (MNCs, FDI). The Social Dimensions of Political Risk-SDPR is an unchartered territory of political risk. Consequently, on the basis of the analysis of theories of risk, political risk, systems, values and globalization the concept for SDPR is generated. This concept is based on basic assumptions: 1) society is a system whose elements are subsystems; 2) the societal subsystem is at the core of society; 3) the relation between societal subsystem and society is such as the relation element-system; 4) political risk is systemic; 5) values are axial to the system, and their carrier is the societal subsystem; 6) laws are an artificial construct that has only a value function, but is not a value; 7) the incommensurability between values and the above mentioned artificial construct generates $S D P R$ s that are relevant to the risk for society. A formal theoretical and analytical model of SDPR and a value triangle and conceptual index of SDPR based on it are introduced. Key conclusions pertain to the following: the need for reconsider the paradigm of democracy; greater participation of the societal subsystem; need for subsystems' mutual restraint based on the principle of authorities' restraint.
\end{abstract}

Key words: political risk, system of society, social dimensions of political risk SDPR, values, globalization, paradigm of democracy

JEL: D7, D72

\section{Introduction}

Political risk emerged as a separate discipline after World War II. Shortly afterwards, the process of globalization deepened and developed, and accordingly neoliberal economic views in politics gained ground. Considered as the likelihood of reduced or lost profits for international business due to political decisions, political risk was viewed in theory and practice only through the lens of multi-national corporations (MNCs), foreign direct investment (FDI), and, at the beginning, even as generated only in developing countries. Political risk theory has never addressed its social dimensions, conceptualized political risk as systemic, or considered its overall impact on the system of society in its multilayered complexity. The present study aims to redefine political risk as systemic, and as

1 PhD, ORCID 0000-0002-0393-1113 
a result, bring out its social dimensions. In extension of this concept, the question of measuring political risk for society through its social dimensions (SDPR) is also raised, but within the framework of democratic political systems only as more progressive ones. The conclusion assumes the need to reconsider the paradigm of democracy and the necessary systemic changes that would regulate political risk in society. If the end of all limits is "the notion of risk and the risk society" (Beck, 2001, p. 217), the questions of the serial production of risk, the way it is distributed through the allocation of values and the change of the social system as a consequence, create an interest in the origins of system's asymmetry, political apathy, and uncertainty about the future at the individual, national and global levels. R. Sennett's statement about the "fall of the citizen", the "deprivation of the authority for the discussion of power" according to Bauman (2013, p. 63, 67), actually becomes the point of departure in the study, which ends in a conclusion about the fall of the political elite and the risk for society.

In this piece of research the aim is to identify, classify, and analyze SDPRs by proposing a formal analytical and theoretical model as well as an index to measure their impact on society. The major assumption is held that political risk is systemic and has social dimensions. The latter in turn arise from value incommensurability between elements of the social system and are a measure of political risk in it. Through a systemic approach to the analysis of the theories of risk, political risk, the system and social system, values and globalization we will uncover systemic parts and dependencies such as elements, wholeness, relationships, interactions and interplay of elements of society, which we will refer to as subsystems in this study, limited to the five most significant ones - societal, economic, financial, technological, and political. Theoretical and formal modeling methods, mathematical modeling of a synthetic index, which is the final practical outcome of the study, are used.

\section{Social dimensions of political risk: conception and index}

\section{Conceptual apparatus}

Due to complexity, an apparatus of six concepts corresponding to the objectives of the study is used. Hence these concepts are defined as risk, political risk, social system and its subsystems, globalization and values. The result is a summary of all the definitions for SDPR.

To the extent that risk is identified as the highest profit/utility in an environment of uncertainty, we consider it a motivated choice. Its severity and impact are calculated through subjective and objective data and analysis, which makes risk the difference between potentiality and reality. Insofar as risk occurs in the interaction of at least two elements, i.e. in a system, its distribution, in the event 
of an adverse event, it affects not only the risk-taker but also the system where it arises and/or is distributed.

The social system is an open system. Its elements are open subsystems that change their limits of growth through the allocation of values. According to systems theories, centralization as a property of the system progresses to individualization (Bertalanffy, 1973, p. 74), but the individual is an element of the societal subsystem. Thus, the societal subsystem, as the interaction of individuals in their personal, communal and social expression, appears to be the central or core element of the social system. The political subsystem, as the exclusive legislator, is the lawmaker of the system. The economic subsystem is comprised of the business units and their partnerships. The financial subsystem encompasses financial institutions ranging from central banks, commercial and investment banks to insurance and financial intermediaries. The technological subsystem is represented by companies related to the retrieval, storage, processing and trading of the input and output of public databases. The cultural system summarizes the human activity performed in the social system.

Political risk is a systemic risk to society because the subsystem that generates it is the lawmaker of the whole social system. As such, political risk has social dimensions also. The legitimating lawmaking exclusivity of this subsystem is a major cause of change in subsystem boundaries and differences, and this is accomplished through the allocation of values.

Values are the primary cause of human actions, and they provoke systemic processes and generate risk.

Globalization is changing the environment by political means in order to homogenize values, which is why we define globalization as a struggle over value perception or imposition.

As a consequence of the conceptual apparatus defined so far, SDPRs are those dimensions of political risk that are generated by the value incommensurability between the societal subsystem and the laws imposed by the political one, which are in fact artificial rational constructs (Fotev, 2012 p. 138-147) bringing order to the chaos of values and performing a function of values without being a value.

\section{Nature, environment, generation of political risk. A theoretical analysis discovering SDPR}

Establishing the definitions and exploring the subject of this study - SDPR - is possible by considering five theories, whose general relationship can be demonstrated as follows: 1) In risk theory we explore the nature, motives, and distribution of risk. The aim is to show that risk has a dual nature, it is generated in a system and is a motivated choice. 2) In political risk theory, we explore types, factors, and applied methods of analysis, aiming to uncover systemic influence 
and social dimensions. We consider extending the analytical procedures to cover the unexplored social dimensions. 3) Systems theories allow us to identify the environment in which political risk and its dimensions emerge. The structure of this environment is an important indicator of how the systemic nature of political risk is realized. 4) Values theory is given due consideration, based on the assumption that values are the root cause of action. Insofar as action generates risk, the root cause of risk is a misalignment of value understandings. 5) Globalization theory is evidence of the functioning of the social system through an allocation of values.

\section{Risk}

In the 18th century, almost all tools for measuring risk were developed: statistical sampling, statistical significance, probability theory, normal distribution, mean, square deviation, median regression. In his study P. Hristov applies phenomenology as a philosophical method and reveals the importance of human decisions for the whole "life cycle" of risk. The psychological aspect of risk as an essential part of its understanding has found its place in the works of D. Kahneman and A. Tversky, according to whom people use cognitive heuristics in sorting and simplifying information. An individual's conceptions of risk include fear, novelty, stigma, and others, with experience and pattern being part of the individual's behavioral structure implicitly shaped by his or her values. In their article "Decisions under uncertainty: biases and heuristics", D. Kahneman and A. Tversky discuss three types of heuristics for assessing probability: representation (e.g., how representative of the people a lawmaker is); availability (e.g., are there familiar reasons to reject a law); and settings and anchoring (political paradigms) (Kahneman, 1984, p. 350). The conclusions concern the biases and 'calibrated' assumptions leading to error/'error' in decision-making, or political risk, in the context of the object of study. From a mathematical point of view, John von Neumann and Oskar Morgenstern's "Game Theory and Economic Behavior" further elaborates the conclusion that one player's gain is exactly equal to the other's loss, which is a challenge to find a mechanism for success. Players need to choose between alternative (strategies) that have not a clear certainty but a clear probability. The system is an unavoidable part of game theory, both mathematically and socially. J. von Neumann seeks to establish the maximum profit - minimum risk relation, defining it as the most rational choice. He introduces the "maximal procedure" where the decision is based on anticipating the opponent's move according to Copeland (1945, p. 499). The introduction of this theory into politics as a means of conflict resolution raised several questions, which gave rise to the 1971 book "Paradoxes of Rationality. Metagame Theory and Political Behavior" by Nigel Howard. It attacked the rationality principle of classical game theory, arguing for the loss of the "irrational" and the values of rational players. He arrives 
at the idea of a "drama theory", whereby human emotions and social dimensions unaccounted for by "rational choice" theory (game theory) become part of the analytical basis of drama theory (Dochev et al., 2014). To the extent that the USA develops its security doctrine as a means of protecting values (Hristov, 2010, p. $22)$, the values-risk-societal integrity nexus is in effect implemented. In summary, the analysis of risk, in particular political risk, needs to consider multiple factors such as motives, decisions, actions, benefits, probability, calculations, game, drama-emotion, etc. Therefore, it is imperative that the analysis is done through the lens of systems theories to uncover the environment of occurrence and value theories to identify the root cause of its occurrence.

\section{System and subsystems}

Systems theory has a significant place because risk and political risk are the consequence of systemic relationships resulting from reasoned decisions and actions. We make reference to General Systems Theory (GST) by L. f. Bertalanffy and to the cybernetic hierarchy of T. Parsons. The former argues that "social science is the science of social systems" (Bertalanffy, 1973, p. 195). Based on the principle of isomorphism, GST gives us a field to think about the mechanism of law-making in the social system and its outcomes. Insofar as isomorphism implies the similarity of systemic laws and principles, "the parallelism of general concept and even special law in different scientific fields is a consequence of the fact that they are associated with a system and that some general principles apply independently of its nature" (Bertalanffy, 1973, p. 84). This argument, which has become the basis for an entire GST, which in turn has been the basis for the development of other theories and practices, such as cybernetics, information theory, decision theory, topology and relational mathematics, provides a basis for analyzing whether the laws and principles in society are isomorphic to the laws and principles of the system in general. We will conclude on this at the end of the study.

Talcott Parsons, the father of structural functionalism, devoted his life to understanding how society works. He sought to answer the question "by what values does society limit individual freedom of choice in the combination of ends and means?". According to N. Luhmann, the system-theoretic side of the "Action is system" paradigm, T. Parsons demonstrates in a formal model of two components: instrument - means (Instrumental) and satisfaction - goal attainment (Consummatory). The adaptation of the system is internal and external (Luhmann, 2008, p. 21, 22). There are four functions of the system: adaptation, goal attainment, integration, and maintenance of a latent pattern (sustainable model). T. Parsons defines society "as the kind of social system that has the highest degree of self-sufficiency relative to its environment, including other social systems" (Parsons, 2005, p. 20). He also proposes a schematic construction of the orga- 
nization of society in which he assigns the highest place to the cultural system. Beneath this system is society with the societal community, which consists of individuals in roles (here referred to as societal subsystem). The integrative function of the societal community, in fact, is the most significant for society as a whole. But for T. Parsons, this integrative function encompasses "the determination of the obligations arising from loyalty in relation to the societal collective", both in its integrity and in terms of the differentiated statuses and roles within it (Parsons, 1998, p. 25). Hence loyalty integrates the integrating system. Its construction is possible either through shared values or through coercion. His formal model, called cybernetic hierarchy, is a search for the values-conditions relations. Schematically, it is presented in Figure 1a. We will turn this model into a subset model, Figure 1b, to change the hierarchical ordering of the elements of the social system. This transformation offers another view of Parsons's cybernetic hierarchy, which signals a necessity of reordering.

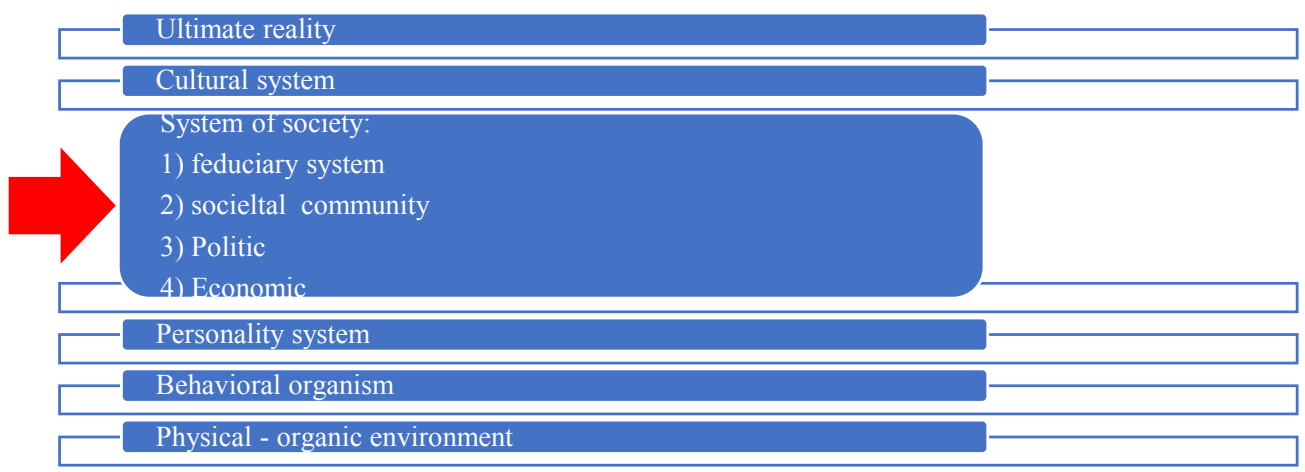

Source: Parsons (2005, p. 23).

Figure 1a: Cybernetic hierarchy of T. Parsons

The behavioral organism and the personality system are the carriers of loyalty, which, as stated above, T. Parsons defines as the integrating capacity of the societal community and they logically precede society in Figure 1a and Figure 1b. The principle of cybernetic hierarchy and the subset model implies that each higher level contains within itself the lower one. Therefore, the behavioral organism and the personality system are included in society. However, in Figure 1a, the societal community occupies the third position in the hierarchy of the system of society (indicated by an arrow), which means that this community includes both the economy and politics. At the same time, the societal community, the social subsystem, is the integrating one for society, and integration is carried 
out through loyalty, which in turn is carried by the lower levels, the behavioral organism, and the personality system.

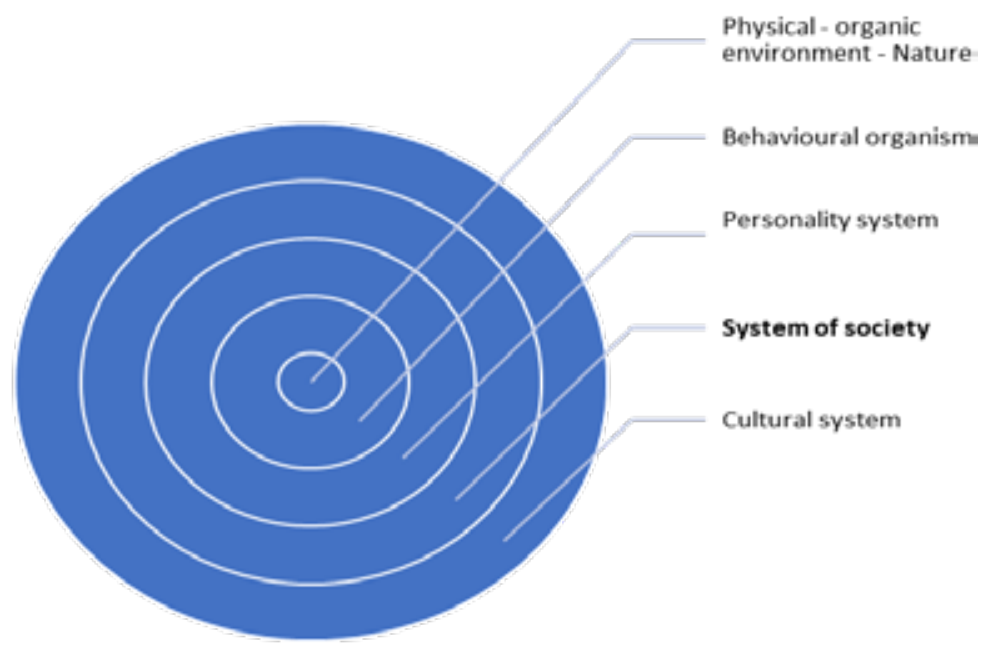

Source: the author

Figure 1b: Representation of the cybernetic hierarchy as a model of subsets

These considerations make us change the place of the societal community of the social system from Parsons' model and place it below the economy and above the personal system, whereby the societal community replaces the economy and ranks first in the system of society (indicated by an arrow in Figure 1a). In the subset model it becomes the basis, the core of the social system. Given the definition of society as an open system whose elements are subsystems, we can represent the societal community, the economy, and politics as subsystems. Let us also add the financial and technological subsystems as separate ones. The argument here is that the financial subsystem is the system of capital, its basic product, the monetary equivalent that is produced physically and according to the rules of the Central Banks, which are part of the political subsystem. In addition, according to the Jubilee Report of the Club of Rome "Come on!", trade turnover is only $2 \%$ of daily capital turnover (f. Vaytszeker, Viykman, 2018, p. 21). At the same time, the technological subsystem "holds" the input and output of public information in the form of massive databases and this makes its place in the social system significant and competitive with the financial and political subsystems. As a result, we arrive at a model of the social system, Figure 2, which should be the environment in which political risk arises. 


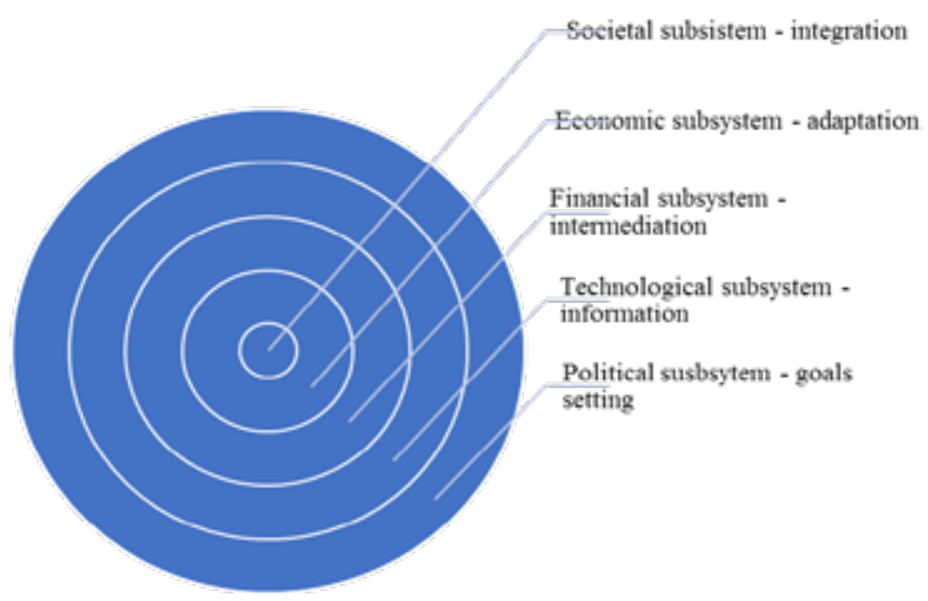

Source: the author

Figure 2: System of society with its elements/subsystems and their functions

If we "insert" the theory of political risk into the system of society referred to in Figure 2, we could hardly limit its object to MNCs or FDI. In its real environment, the political subsystem generates systemic processes and hence systemic risk, because it legislates for the whole system, and a system is more than the sum of its elements - it is constitutive and reproduces emergent relations that are more than the sum of direct single relations, according to the GST (Bertalanffy, 1973, pp. 54-56). In this sense, the types of political risk and analytical approaches to them, currently defined only in relation to the subject of international business, should be supplemented or at least correlated to the SDPR as well.

\section{Political risk}

Jan Bremmer formulates nine types of political risk (Bremmer, 2006, p. 10), of which six are related to international relations in the context of globalization, two are of domestic political origin, and one is neutral to classification. E. Simeonova also adds politically connected crime, collapse of statehood, corruption, regulatory risk, legal unknowns at the individual level, and ethical criticism (Simeonova, 2013, pp. 125-139). In case we summarize the types, we can come up with two main types, and these are "geopolitical" and "domestic political unrest". To the extent that both have been widely studied in scientific literature we will not dwell on them to clarify their essence. But we will propose a new type of political risk, namely technological risk, which is not present in the familiar classifications of political risk. It is the political risk that the entire political subsystem is exposed to, which involves the latter's expropriation by the technological subsystem. Our arguments for introducing this type of political risk 
have to do with its importance for all social subsystems. Technology companies are at the input and output of information exchange - collecting, transferring, archiving, processing, and selling data. To paraphrase H. Mackinder's phrase about the ruler of the world, we can say that he who rules the global databases, rules the world. In this context, the political subsystem is in direct competition with the financial and technological subsystems, given that the main political instruments are information and money. Hence the political subsystem is strongly dependent on the financial and technological subsystems. In addition, financial ecosystems that imply a complete change of the financial business are secured and served entirely by the technological subsystem. Thus, consequently, the technological subsystem turns out to be the main competitor of the political one. It is this fact that gives rise to the SDPRs related to the inability of the societal subsystem to claim any rights over the technological one. Based on these three political risks - "geopolitical", "internal unrest" and "technological" - we can draw conclusions about the SDPRs. These are presented in Table 1.

Table 1: Transition of Political Risks into direct and indirect Social Dimensions of Political Risk

\begin{tabular}{|c|c|c|}
\hline Political Risk & direct SDPR & indirect SDPR \\
\hline geopolitical & $\begin{array}{l}\text { death, emigration/refugee crisis, } \\
\text { political persecution, ethnic } \\
\text { and ideological fragmentation, } \\
\text { loss of real assets, reduction } \\
\text { or resetting of social and labor } \\
\text { income, personal dramas }\end{array}$ & \multirow[t]{3}{*}{$\begin{array}{l}\text { loss of employment or } \\
\text { financial assets, reduction } \\
\text { or resetting of earned } \\
\text { income, reduction of } \\
\text { employment opportunities, } \\
\text { restriction of personal } \\
\text { freedom, loss of } \\
\text { individuality and identity }\end{array}$} \\
\hline $\begin{array}{l}\text { domestic political } \\
\text { unrest }\end{array}$ & $\begin{array}{l}\text { institutional distrust, political } \\
\text { apathy, coercion for corrupt } \\
\text { behavior, political persecution, } \\
\text { breakdown of the state welfare } \\
\text { system, lack of freedom, } \\
\text { leaving/fleeing the state, } \\
\text { personal dramas, impact on } \\
\text { entitlements, disunity along } \\
\text { different lines }\end{array}$ & \\
\hline technological & $\begin{array}{l}\text { narrowing of privacy, } \\
\text { fragmentation of society, loss } \\
\text { of trust in the state, enforcement } \\
\text { of control, choice }\end{array}$ & \\
\hline
\end{tabular}

Source: the author 
From the tabular analysis of the types of political risk and their transformation in the SDPR, we summarize and formulate four groups of social dimensions of political risk, namely: life chances, entitlements rights ${ }^{2}$, trust/distrust, unity/ disunity.

SDPR "life chances" are the possibility of enjoying one's individual freedom within the outer legal freedom defined by the laws in the environment of the material world. These include indicators of entitlement, opportunity, and level of education; opportunities to gain employment for a fair wage/profit; and cost of living expressed in a consumer basket relative to income. Personal freedom as a basic motive in human behavior and actions can be defined as opportunities for expanding life chances and entitlements rights through self-actualization, free communication, creative-spiritual development in an ecological environment, mobility, inviolability of the body and expressed thought, participation in the social whole. SDPR "entitlements rights" reflect external legal rights or the socalled civil rights, their protection and level of implementation. Some inalienable rights are the right to vote, the right to legislate, the right to freedom of speech and thought, the right to movement, the right to property, the right to protection, the right to privacy, the right to education, health, identity. One major criterion for their sufficiency/insufficiency is SDPR "trust/distrust" in state institutions and participation in the political process. SDPR "unity/disunity" is expressed in migration flows and demographic consequences, as well as in polarization and fragmentation along any principle - ethnic, financial, political, health, technological and others. All types of SDPRs, just like the types of political risk, mutually reinforce and interact with each other.

\section{Values}

The listed SDPRs have the character of values. Numerous authorities in the social sciences refer to values as a factor for bringing about systemic change. D. Easton argues that "limiting individual freedom in order to produce action in politics is called values allocation", according to N. Luhman (Luhman, 2008, p. 49). M. Duverger finds the legitimacy of a power in the fact that "it is consistent with the scheme of legitimacy defined by the system of values and norms, and there is agreement on the question of this scheme" (Duverger, 1999, p. 137). T. Parsons summarizes that the "social means of exchange between differentiated parts of the social system are money, influence, political power, and value preferences" (Парсънс, 1998, p. 45). К. Popper argues that "values need social

2 "Life chances" and "entitlements" are terms borrowed from Ralph Dahrendorf. Dahrendorf was impressed by Amartin Sen's theory described in his book on poverty and hunger as a disaster. For Sen, entitlements are the relation of persons and goods by which their access to and control over these goods is legitimated (Dahrendorf, 1998, p. 19). Dahrendorf defines life chances as the politics of freedom (Dahrendorf, 1998, p. 31). 
support", adding that "once tradition is destroyed, civilization disappears with it" (Popper, 1993, p. 59). G. Fotev, says that values are the main issue of human existence (Fotev, 2012, p. 7), that they are of axial importance for the integration and of cardinal importance for the disintegration of the system, and that below a critical point of the weakening of integration and insurmountability of conflicts, the social system ceases to exist. If the system is action, as Parsons argues, risk is the result of interaction in a system, as it appears from the characteristics of risk in general, and political risk is systemic, which results from the environment of its occurrence, then it follows, by deduction, that values are the main connecting element, because: risk arises as a result of action; action arises as a result of interests; these arise as a result of goals, which are determined by motives, which are determined by needs, which are a consequence of a value system. Thus, by virtue of deduction, risk is a function of values. So, political risk is a function of an incommensurability of values between the subsystems (elements) of society.

The societal subsystem is "value-driven and value-determined in its nature", it is fundamentally different from the others, therefore there is a value "incommensurability" between it and the others. It is the bearer of vital and consummatorial values, which in the case of a serious crisis can trigger a crisis of the system. But the social system is a system of open subsystems for which integration and its consequent stratification is a principle of growth. Values have "axial importance in the integration" of the social system, but also "cardinal importance in the disintegration of the systemic whole." To the extent that internalization, i.e. the integration of values, is a key problem in the sociology of values, "below a critical point of weakening integration and insurmountability of conflicts, the social system ceases to exist" (Fotev, 2012, pp. 138-143) ${ }^{3}$. Hence the idea that measuring the value incommensurability of societal subsystems, conditioned also by the quantitative overlapping of the societal with other social subsystems, will indicate approximately accurately the social dimensions of political risk. If to what has been said so far we take into account the fact that "the transformation of politics into an enterprise requiring training in the struggle for power and the professionalization of managerial political activities" give rise to a problem of values (Weber, 1998, p. 60), we can formulate a value triangle in society. It is expressed in three different contingent values that cause mismatches in the needs of societal subsystems. Simplistically, the value triangle is the dilemma between freedom, power and money. The term "money" refers to the material expression of income/expenditure as a result of financial-economic

\footnotetext{
3 The societal subsystem is original in the text, but the author is referring to what we have summarized here as the social system. But even if it remains as the author stipulates, the cessation of the existence of the societal subsystem, which is the core of the social system, means the cessation of the existence of all subsystems, and therefore of the system. Of course, there may be some short time lag in which one of all enjoys total control.
} 
contractual or consumption relations. "Power" pertains to the right to determine the law of the system, while "freedom" to the right and obligation to comply with the law. In this context account should be taken of I. Kant's understanding that "external legal freedom is the power not to obey any external laws except those to which I have been able to give consent" (Kant, 1977, p. 31). Mathematically we can name this value triangle $-\triangle \mathrm{FPM}$. The freedom-power-money dilemma is experienced by homosapiens, homopoliticos, homoconsumos through the incommensurability of the values of the societal subsystem with others in the processes of goal-setting through norms (politics), adaptation (economics), intermediation (finance), information exchange (technology). It thus expresses the problem of integration and the integrity of society, that is, its risk. The value triangle is therefore inscribed in the system of society. One vertex of the triangle located in the social system is "freedom" - the highest societal value. The other is "money" - the generalized economic values and the third is "power" - the generalized political values. Freedom is the highest value for all subsystems, but it has different dimensions: the societal subsystem aspires towards reaching spiritual, political, and economic freedom; the economic subsystem - towards achieving regulatory and market freedom; the political subsystem - towards reaching the freedom to impose and exercise power. According to the classification of M. Scheler, power and money rank significantly lower than freedom as a value in the societal subsystem and highest in the other subsystems, according to Fotev (2012, p. 133). A crisis of values occurs values become meaningless. Then the systemic political risk arises because "a crisis in one sphere or subsystem of society has consequences for others", according to G. Fotev. Moreover, the crisis of values has "axial significance" for the system, shown in Figure 3. Values cut across all subsystems of society. Thus, the positioning of the vertices of the values triangle on the system of society indicates their configuration, and the intersection of the sides of the triangle with the subsets of subsystems - the participation of subsystems in this configuration. Three possible configurations are depicted in Figure 3. The three value triangles respectively $-\Delta \mathrm{F} 1 \mathrm{P} 1 \mathrm{M} 1, \Delta \mathrm{F} 2 \mathrm{P} 2 \mathrm{M} 2, \Delta \mathrm{F} 3 \mathrm{P} 3 \mathrm{M} 3 \mathrm{dem}-$ onstrate different positions and shapes of the triangle, a different ratio of angles, and a different intersection of the subsystems of society. 


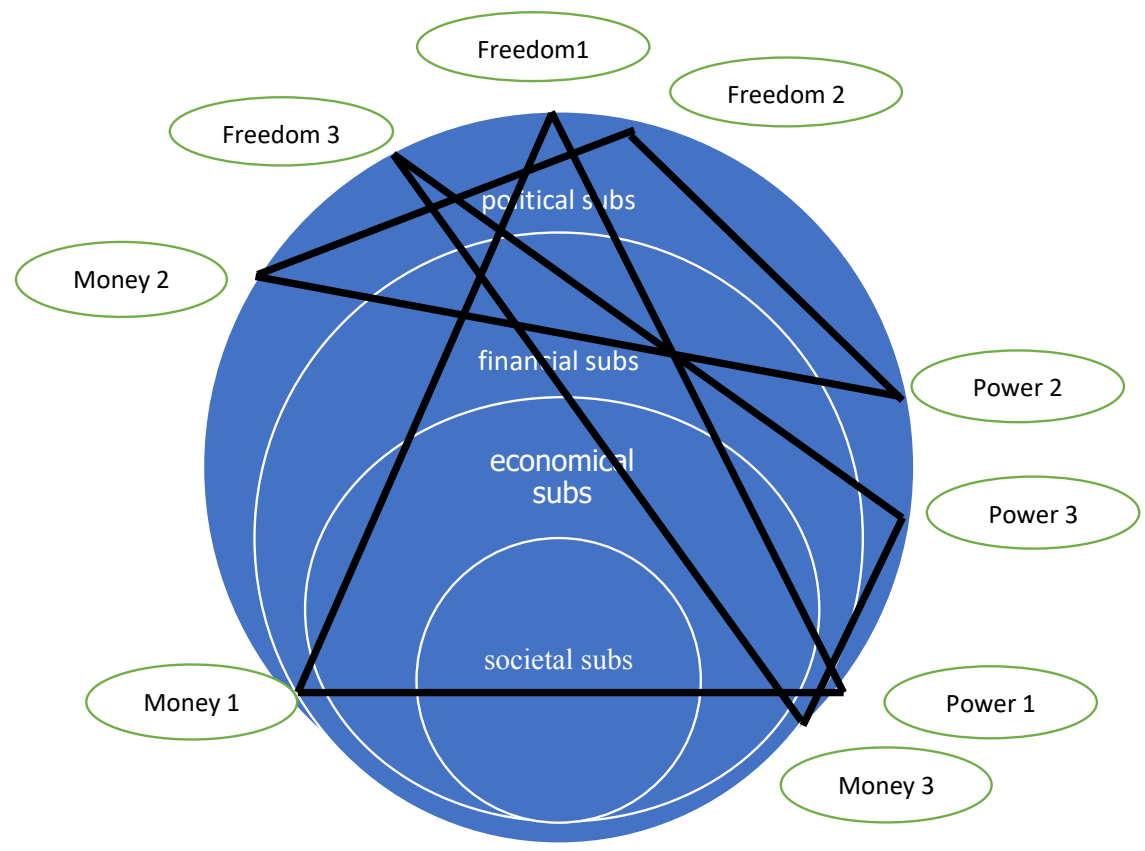

Source: the author

Figure 3: Value triangle of the social system

\section{Globalization}

In the conditions of globalization, value incommensurability and dilemmas provoke a struggle for value perception and that way change the boundaries of subsystems. We find this conclusion in Z. Bauman, who considers the most important global value movement or mobility, which is to a large extent an emanation of freedom. His work "Globalization: The Human consequences" is a guide to the system of globalization as conceived and realized through the construction of the values necessary for it. He identifies multiple social dimensions of political risk, without using this term, as separate or combined dimensions of political, economic, financial, technological or social direction of globalization. We could illustrate this in Table 2, which summarizes this conclusion by presenting similarity of Z. Bauman's view of globalization to the types of SDPRs already defined above. 
Table 2: SDPR in Z. Bauman's theory.

\begin{tabular}{|l|l|l|l|}
\hline SDPR Life's Chance & \multicolumn{1}{|c|}{$\begin{array}{c}\text { SDPR Entitlements } \\
\text { rights }\end{array}$} & \multicolumn{1}{|c|}{$\begin{array}{c}\text { SDPR Unity/ } \\
\text { Disunity }\end{array}$} & \multicolumn{1}{c|}{$\begin{array}{c}\text { SDPR Thrust/ } \\
\text { Untrust }\end{array}$} \\
\hline $\begin{array}{l}\text { loss of value } \\
\text { orientation }\end{array}$ & $\begin{array}{l}\text { oversupply vs. } \\
\text { regulated to over- } \\
\text { control society }\end{array}$ & $\begin{array}{l}\text { "wanderers" versus } \\
\text { "global tourists", } \\
\text { local versus global }\end{array}$ & $\begin{array}{l}\text { Replacement of } \\
\text { places in the social } \\
\text { structure. Finance and/ } \\
\text { or technology strive to } \\
\text { the core. }\end{array}$ \\
\hline $\begin{array}{l}\text { Synopticum } \\
\text { - maximum } \\
\text { homogenization of } \\
\text { values and thinking }\end{array}$ & $\begin{array}{l}\text { socio-cultural } \\
\text { hierarchy: "global } \\
\text { tourists", the } \\
\text { Synopticum, finance, } \\
\text { technology and mass } \\
\text { media, the economy, } \\
\text { voters - legitimators. }\end{array}$ & $\begin{array}{l}\text { Focus on economic } \\
\text { growth, markets and } \\
\text { FDI. The societal } \\
\text { supsystem has only a a }\end{array}$ & $\begin{array}{l}\text { Authority taken away } \\
\text { from the people - } \\
\text { social and political } \\
\text { apathy. }\end{array}$ \\
\hline $\begin{array}{l}\text { Predetermined } \\
\text { chances - "maps" are } \\
\text { plotted on territory, } \\
\text { not the other way } \\
\text { around - territory on } \\
\text { maps. }\end{array}$ & $\begin{array}{l}\text { Rejection of the } \\
\text { social subsystem } \\
\text { by depriving it of } \\
\text { authority. }\end{array}$ & $\begin{array}{l}\text { Fragmentation and } \\
\text { alienation at the } \\
\text { "bottom" versus } \\
\text { freedom and unity at } \\
\text { the "top". }\end{array}$ & $\begin{array}{l}\text { Imposing serial } \\
\text { uncertainty as a } \\
\text { function of investment } \\
\text { appetite and risk } \\
\text { allocation (high risk- } \\
\text { high reward) }\end{array}$ \\
\hline
\end{tabular}

Source: classification of the author based on a citation from "Globalization", Z. Bauman (2013).

Summarizing the theoretical understandings and analysis presented above, a conceptual framework for a theory of SDPR is now defined by the following postulates: the societal subsystem is at the core of the social system; political risk is systemic; values are axial to the system, and their carrier is the societal subsystem; laws are an artificial rational construct that has only a value function and brings order to the chaos of values, but is not a value; the incommensurability between values and this artificial construct generates political risk with social dimensions equal to the risk of the whole social system.

\section{Essence of the SDPR concept. Theoretical and formal model of SDPR.}

The nature of the SDPR should be analyzed in terms of the functions of societal subsystems. According to the functional classification of T. Parsons, there are four main functions: adaptation, goal setting, integration, maintenance of a sustainable pattern. The social system itself is followed by the cultural system, which reflects the whole activity of the first one empirically, and therefore carries the civilization model. To the extent that political risk in the context of globalization is responsible for the formation and destruction of the sustainable pattern - the 
civilization model - the analysis concerning primarily the functions of integration, adaptation, goal-setting is directly related to the ability to be performed the function of sustainability. When it is impossible, the social system is destroyed.

The smallest constituent unit of society is the individual, so the societal subsystem is constituted by all people in their personal, community and social interaction, therefore it is resourceful and constructive for all others. This makes its integrative function, postulated by T. Parsons, possible. On the other hand, according to G. Fotev, the societal subsystem is the carrier of the values that are of axial importance for society. Therefore, the place of the societal subsystem as the core of the whole social system is legitimized (if we use M. Weber's expression of sustainability). It participates in the political subsystem through relevant roles, but the main function of the political subsystem is goal setting. These goals should be public, collective and correspond to the values of the societal subsystem. But being the exclusive holder of the law-making rights in the social system, the political subsystem realizes its own values, the main one being power. Here is the first value misalignment that the SDPR generates. Adaptation within the system, again following T. Parsons, is carried out by the role activities of the societal subsystem in the economic and financial one. Fundamentally, the purpose of the economic subsystem is to ensure survival, i.e., the production of goods and services necessary to sustain vital functions. But, in fact, this system has "transcended" the need for sufficiency and, with the mechanisms of economic growth, has developed an independent core value, namely, sales and profit maximization. On the one hand, economic growth is an essential part of the rhetoric of the political subsystem in the process of securing its legitimacy; on the other hand, economic growth is made possible by the means of the financial subsystem capital, credit, interest, currency, derivatives. The financial subsystem has won the rights of a universal measure of development for all subsystems: income for the societal subsystem, profit for the economic subsystem and the state budget for the politic al subsystem. It also plays a major role in the accumulation and distribution of personal (individual), community (corporate) and public (state) capital, assets and resources. In this sense, by accumulating resources from all other subsystems, the financial subsystem makes them functionally dependent on itself. But the political subsystem is the law generator of the system and it creates normative dependence of others on itself. Thus, the financial subsystem, through its function as an agent of capital, outlives the value of both the economic and political subsystems - maximizing power and profit. This is a competition, insofar as the exclusivity of the political system to determine the law is made contingent on the exclusivity of the financial subsystem to accumulate and distribute the resource that the law is supposed to manage. The economic and financial subsystems do not have sufficiency defined in terms of their underlying 
value justification - sales and profit maximization. This predetermines the lack of a notion of sufficiency in the legal construct defining their functioning, which is in fact a lack of constraint for the political subsystem in terms of its legislative activity. Consequently, the political subsystem "lives" its core value - power-also in the indeterminacy of sufficiency. The technology subsystem creates, collects, processes, stores, transports, trades the entire database array of all subsystems. Without being legislative or the core of the system it functionally places all subsystems in dependence on itself and without claiming a kind of first place it continuously unfolds unrestrictedly throughout the system integrity. At the same time, the societal subsystem, being the core of any social subsystem, is defined in the limitlessness of the others, which limits its basic value - freedom. Here arises the second inconsistency of sub-systems' values. This setup determines the distribution in the value triangle $\Delta$ Freedom, Power, Money, where the restriction of the Freedom angle expands the other two - Money and Power. We can assume that the cause is a "defect" in the law of the system, or in the law-making process, or in the structure of the system itself. The defect generates risk, and risk is political because the law is produced in the political subsystem. Political risk thus acquires social, economic, financial, and technological dimensions. The social dimensions concern the core of the social system and its subsystems and are therefore most relevant to the risk of the whole system. The other dimensions are superficial, in terms of systemic form, and are governed by the principles of diversification (economics and finance), coercion (politics) or the inability to opt out (technology). What all have in common is their bidirectional influence on the cultural system. When this influence leads to a distancing of the cultural system from the social system, a larger civilizational upheaval/ disruption is registered. If we introduce the value triangle of society as an indicator of this possibility and consider the eight civilizations of S. Huntington ${ }^{4}$, then under the conditions of globalization we can assume a "civilizational clash" as a result of the SDPR calculated in eight different value triangles that they construct.

Let us reiterate that political risk derives from the system (system theory), the system from action (T. Parsons), action from interest, interest from goals, goals from needs, and needs from values (value theory). If we use A. Maslow's famous pyramid of needs, from the incommensurability of subsystem needs we could infer the incommensurability of subsystem values that generate SDPR. As a result the value triangle of society will be constructed. The latter will give an idea of the risk levels within the entire social system. Comparing the needs of social subsystems with Maslow's pyramid of needs that concerns the individual is admissible by referring to the principle of isomorphism, on which L. f. Bertalanffy based the

${ }^{4}$ Western, Eastern Orthodox, Islamic, Buddhist, Hindu, African, Latin American, Zionist and Japanese. 
GST, proving that even a person in themselves is also a system, and all systems abide by the same principles and laws.

Maslow's pyramid of needs encompasses six levels. Each successive one represents a need that should emerge and be satisfied if the previous one is achieved. The final sixth need - transcendence A. Maslow introduced before his death. In ascending order, the needs are: 1) physiological needs/survival; 2) security; 3) belonging; 4) confidence; 5) self-actualization; 6) transcendence. We work with three values - freedom, money and power and their combination, and with Parson's four AGIL functions (adaptation, goal setting, integration, latent model). In Table 3 the needs are placed vertically, and the five social subsystems are placed horizontally. The last column on the right are the SDPRs resulting from the asymmetry of the subsystems' needs, consequently - values.

Table 3: Generation of SDPRs as a result of the mismatch of needs of societal subsystems

\begin{tabular}{|c|c|c|c|c|c|c|}
\hline $\begin{array}{c}\text { Subsystem/ } \\
\text { need }\end{array}$ & Societal & Economics & Financial & Technological & Political & SDPR \\
\hline Survival & adaptation & integration & integration & integration & integration & trust/ untrust \\
\hline Security & $\begin{array}{l}\text { integration, } \\
\text { adaptation }\end{array}$ & $\begin{array}{l}\text { integration, } \\
\text { adaptation }\end{array}$ & $\begin{array}{l}\text { integration, } \\
\text { adaptation }\end{array}$ & $\begin{array}{l}\text { integration, } \\
\text { adaptation }\end{array}$ & latent pattern & $\begin{array}{l}\text { entitlements } \\
\text { rights }\end{array}$ \\
\hline Belonging & $\begin{array}{l}\text { latent pattern, } \\
\text { integration }\end{array}$ & no & no & no & $\begin{array}{l}\text { latent pattern, } \\
\text { integration }\end{array}$ & $\begin{array}{l}\text { unity / } \\
\text { disunity }\end{array}$ \\
\hline Confidence & $\begin{array}{l}\text { goal attainment } \\
\text { - development }\end{array}$ & $\begin{array}{l}\text { goal } \\
\text { attainment: } \\
\text { maximization } \\
\text { of the profit }\end{array}$ & $\begin{array}{l}\text { goal } \\
\text { attainment: } \\
\text { profit } \\
\text { capitalization, } \\
\text { consumption } \\
\text { expansion }\end{array}$ & $\begin{array}{l}\text { goal attainment: } \\
\text { fields } \\
\text { enlargements } \\
\text { and users' } \\
\text { growth }\end{array}$ & $\begin{array}{l}\text { goal } \\
\text { attainment: } \\
\text { power }\end{array}$ & life's chances \\
\hline $\begin{array}{l}\text { Self- } \\
\text { actualization }\end{array}$ & $\begin{array}{l}\text { freedom for } \\
\text { development }\end{array}$ & $\begin{array}{l}\text { freedom } \\
\text { for profit } \\
\text { maximization }\end{array}$ & $\begin{array}{l}\text { freedom } \\
\text { for profit } \\
\text { capitalization }\end{array}$ & $\begin{array}{l}\text { freedom to } \\
\text { maximization } \\
\text { the users' } \\
\text { number and } \\
\text { applications, } \\
\text { artificial } \\
\text { intellect } \\
\text { introducement }\end{array}$ & $\begin{array}{l}\text { freedom for } \\
\text { power }\end{array}$ & life's chances \\
\hline $\begin{array}{l}\text { Trans- } \\
\text { cendence }\end{array}$ & $\begin{array}{l}\text { world civil } \\
\text { society }\end{array}$ & $\begin{array}{l}\text { unrestricted } \\
\text { access to } \\
\text { markets and } \\
\text { resources }\end{array}$ & global capital & $\begin{array}{l}\text { global and total } \\
\text { digitalization }\end{array}$ & $\begin{array}{l}\text { globally } \\
\text { legitimated } \\
\text { power }\end{array}$ & $\begin{array}{l}\text { entitlements } \\
\text { rights }\end{array}$ \\
\hline
\end{tabular}

Source: the author 
By interpreting each line that exposes how the SDPR is formed, the following comments should be made: at level one - survival, we can conclude that the societal subsystem is in constant adaptation, while the other four are in constant integration, which means change for the first and development for the others. The more difficult the adaptation to the constantly changing processes, the lower the trust in the societal subsystem to the political one. Trust in the political subsystem is a source of stability and legitimacy for the government, and therefore contributes to a sustainable model. Conversely, distrust (political or other) can find expression in political apathy, participation in corruption, civil discontent or riots, flight or immigration, which shakes the sustainability of the model and creates the conditions for risky events.

On the second line - security - the societal, economic, financial and technological subsystems provide this need through integrative and adaptive functions, while the political function ensures the maintenance of the model. This level of need is linked to the SDPR "entitlements rights". If the political system changes the model due to its legislative exclusivity, this affects the entitlements rights and triggers the $\mathrm{n}$ eed for adaptation. Here, SDPRs can be summarized as participation in politics, economics, finance and technology.

On the third line - belonging - we make a connection with the SDPR "unity/ disunity". From this level the serious inconsistencies between the subsystems begin to emerge. Belonging to the societal subsystem does not imply ownership only and is sensitive rather than a material experience. It may also be the result of choices that are inherently rational or irrational. In this sense, there is an opposition of the needs of the societal and the political subsystems versus the economic, financial and technological ones. The former two strive to maintain the model and integrate, whereas the latter three have no need for belonging. Furthermore, a discrepancy has been observed between the first two subsystems in the functional realization of their needs: that is, rationality and irrationality of choice. At this level, SDPR can manifest itself in emigration, ethnic divisions, financial, elitist, educational fragmentation, or polarization.

At levels four to six, a path to satisfaction is sought with values of a higher rank, and accordingly at that level SDPR "life chances" is introduced. At level four confidence - the five subsystems function in the same way - goal attainment, but each with regard to different values. Here the significant differences arise. Here, according to the type of the values triangle, the biggest number of political risks for the societal subsystem is realized and the risks are related to the subsystem's development prospects involving education, health, quality of life, social position.

At level five - self-actualization - the five subsystems face one value freedom, but in a subsystem-specific value sense. The distinction becomes even more significant insofar as competition is created between the subsystems, which will determine the life chances for a breakthrough to a new level of development. 
The last, sixth level, transcendence, can be said to be an end point. For the societal subsystem this is a global civil society, for the economic subsystem it is unlimited access to markets and resources, for the financial subsystem it is global capital, for the technological subsystem it is global digitalization, and for the political subsystem it is a globally legitimated government. For the whole social system, it is a sustainable cultural-civilizational model. So, here we are talking about SDPR "entitlements right" as specifically related to the participation of the societal subsystem in the legislative process.

In summary, we can conclude that up to level three the subsystems functionally satisfy their needs, but from level four upwards, value justifications and differences emerge that generate more substantial SDPR. This is confirmed by the fact that the main political argument is survival, security and belonging. Here, social risks are clearly distinguished from SDPRs, explained by replacing the individual character of risk by a homogenization of the collective risk level. Self-actualization and transcendence are vehicles of conflict between subsystems insofar as they express similar values but in different value senses.

The formal model of SDPR is based on the concept of the nature of SDPR already presented, and therefore on the following understandings in the causality mentioned: 1) the incommensurability of the values of the subsystems of society provokes 2 ) an incommensurability of their needs, which are 3) limited within the norms and laws defined by the political subsystem, therefore 4) political risk is generated. 5) Political risk has economic and social dimensions. 6) Because the societal subsystem is the carrier of values, SDPRs are highly important for the risk in the social system and 6) induce, to varying degrees, changes in other subsystems as well as in the social system. This interrelationship - a formal model of the SDPR - is shown in Figure 4.

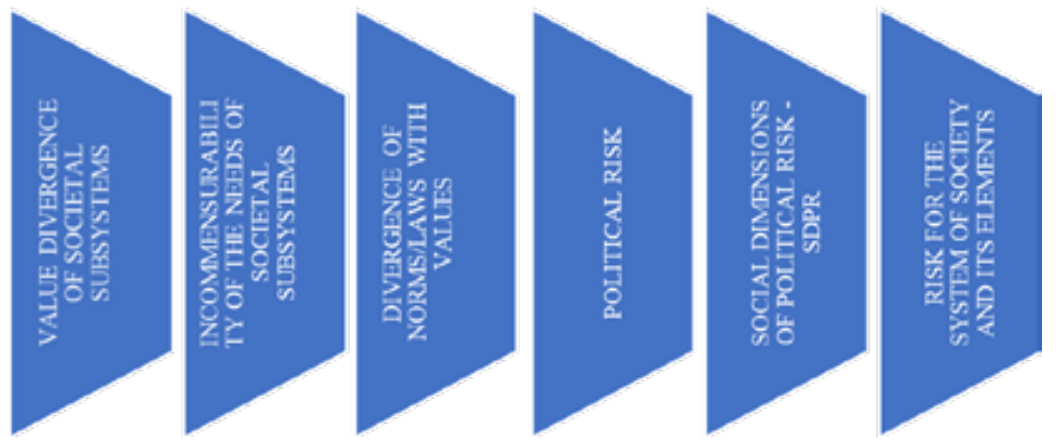

Source: The author

Figure 4: Formal SDPR model 
In a more concise way, the formal model can be represented in Table 4. It highlights three levels of the relationship between value incommensurability, SDPR and the risk to the social system.

Table 4: Effect of the SDPR on the social system

\begin{tabular}{|l|l|l|l|}
\hline $\begin{array}{c}\text { Difference between values } \\
\text { of the societal subsystem } \\
\text { and laws/norms imposed } \\
\text { by the political subsystem }\end{array}$ & $\begin{array}{c}\text { Comparison of the needs } \\
\text { of the societal subsystem } \\
\text { with the needs of the other } \\
\text { subsystems }\end{array}$ & SDPR & $\begin{array}{c}\text { Risk to the } \\
\text { social system }\end{array}$ \\
\hline drastic difference & opposite & high & collapse \\
\hline average difference & divergence & medium & destabilization \\
\hline little difference & coincidence & low & correction \\
\hline
\end{tabular}

Source: the author

When there is a drastic difference in the values of the societal subsystem and the laws/norms imposed by the political subsystem, opposing needs are provoked between the elements/subsystems of the social system. The social dimensions in this case are of such values that they imply a collapse of the social system. Two more risk levels are considered - destabilization and correction, which are achieved at values of SDPR resulting from a relatively non-drastic divergence or coincidence of needs of the elements/subsystems of society. It should be noted that the second level should be divided into at least two distinct levels, depending on how large the gap is. In this case, insofar as the model is formal, it is not assumed to explore all possible value/law relationships. Table 4 will be the basis for constructing an SDPR index that demonstrates the relation between SDPRs and the risk to the social system.

If we go back to the value triangle of society (Figure 3), we see that there is a relationship between the SDPRs and its corners. For example, the "Freedom" and "Money" corners directly correspond to the SDPRs "Entitlements rights" and "Life chances". The 'Power' corner can be related to the SDPR "trust/distrust", "unity/ disunity". This means that there is a relationship between the shape of the value triangle and the risk to the social system, determined precisely by the SDPR.

\section{Conceptual model of SDPR index - SDPRIx}

The SDPR Index - SDPRIx is based on qualitative and quantitative models for political risk analysis. Analytical, synthetic, and mathematical methods are applied to achieve a finite numerical and geometric expression. The components of the index are divided into three levels: factors of SDPRs, types of SDPRs, dimension of the value triangle in the social system. The logic of this distribution lies in the 
fact that the types of SDPR always interact and coexist in different proportions. Their distribution measures values that are also interdependent: internal "freedom" is achievable within the external one defined by "power" through laws in the material world that is defined by "money". We launch such an argument because these values are held by all subsystems of society, though in different ways, and the societal subsystem is at the core of each subsystem, which makes the former determinative for the maintenance of risk. For example, "freedom" and "money" are directly related to "life chances" and "entitlements rights"; "power" to "trust/ distrust" and "unity/disunity". Hence increases in "Power" bring about decreases in "Freedom" and "Money". The recalculation of the SDPR into a value triangle represents the impact of political risk on the social system as a whole. So, because political risk is systemic, and the societal subsystem is the carrier of values, the SDPR have a significant impact on the entire social system, making them an essential source of information and analysis, as well as an important consideration in planning both investment and policy change. We have shown that the system of society is a construction of subsets of subsystems that are presented in the form of concentric circles. We selected five influential subsystems, which do not provide an exhaustive coverage of all types. The distance between subsystems is a measure of the participation of each subsystem in society. This construction mathematically requires working with a model of inscribed figures in a circle. Insofar as the goal of the SDPR Index is the graphic model of the value triangle, it is logical to approach the inputs of the index also geometrically. There are four SDPRs, which when presented as a figure form a quadrilateral whose regular shape is a square. The sum of the angles of a quadrilateral is $360^{\circ}$, and in a square each angle is $90^{\circ}$. The sum of the vertices of a triangle is always equal to $180^{\circ}\left(360^{\circ} / 2\right)$, and its regular shape is an equilateral triangle, where each angle is $60^{\circ}$. We use regular figures carrying information about ideal values, which we adjust to the real ones. The rationale behind this approach as an idea is taken from risk theory, specifically Galton's idea that the presence of a normal distribution implies the presence of homogeneity and the absence of homogeneity implies the presence of a divergent system, from which we take the idea of mean regression that motivates almost all risk decisions (Bernstein, 1996, p. 170). In addition, any comparison requires a model for comparison. Moreover, the purpose of politics, ideally, is to balance the social system through laws. So, the ideal balance between the three values of the value triangle is equality. Therefore, we use regular geometric shapes that we further adjust using the real size of the SDPRs types. We follow three steps: 1) calculate the types of SDPRs, 2) calculate the angles of the value triangle, 3) calculate the participation of the subsystems in society using the distances between them.

The change in the types of SDPRs changes the size of the angles "Freedom", "Power", "Money". Because the political risk is systemic and is produced by the 
power subsystem - the political one, the analysis of the SDPRIx is focused on the "Power" angle, from whose size conclusions are drawn about the risk level of the social system. Thus, through the prism of equidistant subsystems, regular figures with static primary, ideal sizes of $90^{\circ}$ for each SDPRs type and $60^{\circ}$ for each angle in value triangle, we will calculate their actual sizes. We achieve this by: first - decreasing/ increasing the SDPR sizes in result of their factors; second - using the new SDPRs' sizes, we adjust the ideal dimensions of the triangle angles and subsystem distances. According to what size the three vertices of the triangle have, respectively "freedom", "money", "power", the type of the triangle is inferred. Its location in the circle of the social system, the risk for the social system and its subsystems is directly dependent on the participation of each subsystem, measurable with the distances between them.

Schematically presented in Table 5, the components of the SDPRIx are three: SDPR factors, SDPR types, angles of the value triangle.

Table 5: Components of the SDPR index

\begin{tabular}{|c|c|c|c|c|c|}
\hline $\begin{array}{l}\text { SDPR } \\
\text { types }\end{array}$ & $\begin{array}{c}\text { Trust/ } \\
\text { untrust }\end{array}$ & $\begin{array}{l}\text { Entitlements } \\
\text { rights }\end{array}$ & Life's Chance & Unity/disunity & $\begin{array}{c}\text { VALUE } \\
\text { TRIANGLE }\end{array}$ \\
\hline \multirow{6}{*}{ 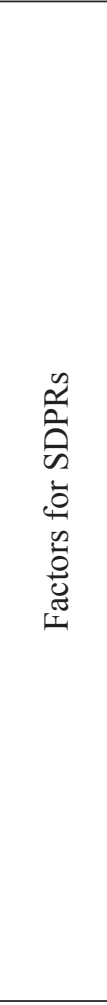 } & $\begin{array}{l}\text { institutional } \\
\text { trust }\end{array}$ & $\begin{array}{l}\text { participation } \\
\text { at the political } \\
\text { subsystem: } \\
\text { public position, } \\
\text { participation at the } \\
\text { legislative process }\end{array}$ & $\begin{array}{l}\text { health, } \\
\text { healthcare }\end{array}$ & $\begin{array}{l}\text { ethnic and } \\
\text { religious } \\
\text { fragmentation }\end{array}$ & \multirow[t]{2}{*}{ Freedom } \\
\hline & $\begin{array}{l}\text { political } \\
\text { apathy }\end{array}$ & $\begin{array}{l}\text { participation in the } \\
\text { redistribution of } \\
\text { public goods }\end{array}$ & $\begin{array}{l}\text { education, } \\
\text { culture, } \\
\text { socialization }\end{array}$ & $\begin{array}{l}\text { social } \\
\text { fragmentation }\end{array}$ & \\
\hline & $\begin{array}{l}\text { ideological } \\
\text { apathy }\end{array}$ & $\begin{array}{l}\text { freedom of speech, } \\
\text { movement, right to } \\
\text { property and self- } \\
\text { defense }\end{array}$ & $\begin{array}{l}\text { quality of life - } \\
\text { material, } \\
\text { spiritual and } \\
\text { emotional, } \\
\text { ecology }\end{array}$ & $\begin{array}{l}\text { ideological } \\
\text { and political } \\
\text { fragmentation }\end{array}$ & Power \\
\hline & $\begin{array}{l}\text { acceptance } \\
\text { of a corrupt } \\
\text { pattern of } \\
\text { behavior }\end{array}$ & $\begin{array}{l}\text { participation at } \\
\text { the economic } \\
\text { and financial } \\
\text { subsystem }\end{array}$ & $\begin{array}{l}\text { material } \\
\text { property }\end{array}$ & $\begin{array}{l}\text { financial } \\
\text { polarization }\end{array}$ & \multirow[t]{3}{*}{ Money } \\
\hline & civil protests & $\begin{array}{l}\text { right and level } \\
\text { of awareness } \\
\text { and protection }\end{array}$ & & $\begin{array}{l}\text { educational, } \\
\text { techno } \\
\text { and elitist } \\
\text { fragmentation }\end{array}$ & \\
\hline & & education & $\begin{array}{l}\text { emigration, } \\
\text { mobility }\end{array}$ & other signs & \\
\hline
\end{tabular}

Source: the author 
The process of transforming the data from SDPR factors to SDPR types' data, to values triangle's data, to a conclusion about the location of the triangle in the social system and its risk level follows the logic outlined in Table 6 . To the extent that the trust/distrust and unity/disunity SDPRs are opposite, in order to simplify the analysis to one variation, we will assume the negative dimensions for the purpose of the index. We give short conventional labels as follows: SDPR "life chances" - LC, SDPR "entitlements rights" - ER, SDPR "disunity" - DU, and SDPR "distrust" - DT. Next, we need to establish the interdependencies between them. Since the sum of the angles of each quadrilateral is $360^{\circ}$ then LS $+\mathrm{ER}+\mathrm{DU}+\mathrm{DT}=360^{\circ}$. Doing the same for the value triangle, we give short conventional labels as follows: $\mathrm{P}$ for power, $\mathrm{F}$ for freedom and $\mathrm{M}$ for money. Since the sum of the angles of a triangle is $180^{\circ}$, then $\mathrm{P}+\mathrm{F}+\mathrm{M}=180^{\circ}$. The variable $\alpha$ indicates the social subsystem's value attitude towards freedom, which is related to spiritual biases. The variable $\beta$ indicates attitude toward money, which is related to material biases. Thanks to $\alpha$ and $\beta$, where $\alpha+\beta=100 \%$, we achieve a numerical expression of the social attitude freedom-money, spirit-matter.

Table 6: Process for generating and implementing the SDPR index

\begin{tabular}{|c|c|c|c|c|c|}
\hline $\begin{array}{c}\text { SDPR } \\
\text { factors by } \\
\text { type }\end{array}$ & $\begin{array}{l}\text { Valuation of } \\
\text { each type } \\
\text { SDPR }\end{array}$ & $\begin{array}{l}\text { Valuation of angles of } \\
\text { value triangle }\end{array}$ & $\begin{array}{l}\text { Value } \\
\text { of angle } \\
\text { "Power" }\end{array}$ & $\begin{array}{l}\text { Risk for } \\
\text { the social } \\
\text { system }\end{array}$ & $\begin{array}{c}\text { Decision } \\
\text { making } \\
\text { processes }\end{array}$ \\
\hline \multirow{5}{*}{$\begin{array}{l}0 \\
0 \\
0 \\
0 \\
0 \\
0 \\
0 \\
0 \\
0 \\
0 \\
\Xi \\
0 \\
0 \\
000 \\
: 0 \\
0 \\
0 \\
0 \\
0 \\
0\end{array}$} & Trust/ distrust & \multirow{2}{*}{$\begin{array}{l}\text { Freedom } \\
\text { Function of SDPR } \\
\text { "entitlements rights" } \\
\text { and "life chances" } \\
\text { adjusted by } \alpha \text {. }\end{array}$} & \multirow{2}{*}{$\begin{array}{l}\text { Power } \geq \\
120^{\circ}\end{array}$} & \multirow[t]{2}{*}{ High } & \multirow{4}{*}{$\begin{array}{l}\text { Political } \\
\text { reforms. } \\
\text { Economic } \\
\text { decisions } \\
\text { according } \\
\text { to risk } \\
\text { appetite. } \\
\text { Social } \\
\text { changes } \\
\text { according } \\
\text { to any } \\
\text { SDPR } \\
\text { type's size }\end{array}$} \\
\hline & $\begin{array}{l}\text { Entitlements } \\
\text { rights }\end{array}$ & & & & \\
\hline & Life chances & $\begin{array}{l}\text { Money } \\
\text { Function of SDPR } \\
\text { "entitlements rights" } \\
\text { and "life chances" } \\
\text { adjusted by } \beta \text {. }\end{array}$ & $\begin{array}{l}60^{\circ} \geq \\
\text { Power }< \\
120^{\circ}\end{array}$ & Medium & \\
\hline & $\begin{array}{l}\text { Unity/ } \\
\text { disunity }\end{array}$ & $\begin{array}{l}\text { Power } \\
\text { Sum of SDPR } \\
\text { "disunity" and } \\
\text { "Distrust" }\end{array}$ & $\begin{array}{l}\text { Power }< \\
60^{\circ}\end{array}$ & Low & \\
\hline & $360^{\circ}$ & $180^{\circ}$ & & & \\
\hline
\end{tabular}

Source: the author

Summarizing, we apply the following postulated and principled rules here: 


\section{Political Science:}

The "Freedom" angle of the values triangle is formed by the SDPR "Life Chances" and the "Entitlements Rights" i.e., F is formed by (LC + ER), modified with $\alpha$;

The "Money" angle of the value triangle is formed by the SDPR "Life Chances" and "Entitlements rights", i.e. $M$ is function of (LC + ER), modified with $\beta$;

The "Power" angle of the values triangle is formed by the sum of SDPR "Distrust" and "Disunity", i.e. P is function of (DT + DU).

\section{Mathematical:}

Because the sum of angles in the quadrilateral is $360^{\circ}$, and the sum of angles in the triangle is equal to $360^{\circ} / 2=180^{\circ}$, then $\mathrm{P}=(\mathrm{DU}+\mathrm{DT}) / 2$.

$\mathrm{ER}+\mathrm{LC}+\mathrm{DU}+\mathrm{DT}=360^{\circ}$

$\mathrm{DU}+\mathrm{DT}=360-(\mathrm{ER}+\mathrm{LC})$

$360^{\circ} / 2=180^{\circ}=\mathrm{F}+\mathrm{M}+\mathrm{P}$

$\mathrm{P}=(\mathrm{DU}+\mathrm{DT}) / 2$, and because $\mathrm{F}+\mathrm{M}+\mathrm{P}=180^{\circ}$, then $\mathrm{M}+\mathrm{F}=180^{\circ}-\mathrm{P}=$ $180^{\circ}-(\mathrm{DU}+\mathrm{DT}) / 2$,

$\mathrm{F}=180^{\circ}-(\mathrm{DU}+\mathrm{DT}) / 2 * \alpha \%$

$\mathrm{M}=180^{\circ}-(\mathrm{DU}+\mathrm{DT}) / 2 * \beta$, where $\alpha+\beta=100 \%$.

We can now derive a formula for the final score of the SDPRIx, namely its geometric form in a value triangle to account for risk in society:

$\mathrm{F}+\mathrm{M}+\mathrm{P}=(\mathrm{DU}+\mathrm{DT}) / 2+\left(180^{\circ}-(\mathrm{DU}+\mathrm{DT}) / 2\right) * \alpha \%+\left(180^{\circ}-(\mathrm{DU}+\right.$ $\mathrm{DT}) / 2)^{*} \beta \%(1)$

The calculation of the SDPRs is based on the understanding that a decrease/ increase in one of the SDPRs type below/above the ideal values of $90^{\circ}$, respectively, implies an inverse, summed proportional increase/decrease in the other three. Logic and practice lead us to the following conclusions: an increase in "entitlements rights" also increases "life chances", whereby "distrust" falls, and a fall in distrust leads to a fall in "disunity". "Distrust" increases with decreasing entitlements rights" and high values of "disunity". We can therefore formally represent the dependencies of the four SDPRs as a reflection of the deviation of one SDPR from the ideal value $\left(90^{\circ}\right)$ in the sum of the proportional, positive, or negative, variation of the other SDPRs. This inference is formalized in Table 7. In the fourth column, the increase/ decrease in SDPR "entitlements rights" leads to the increase/decrease in SDPR "life chances", and the decrease/increase in the SDPRs "disunity" and "distrust". Columns five, six and seven show the dependencies between the other SDPRs. An increase/decrease in SDPRs "life chances" and "distrust" is not necessarily associated with a change in SDPR "entitlements rights". 
Social Dimensions of Political Risk - SDPR: Concept and Index for Risk Impact on Society

Thus, a $1^{\circ}$ increase in ER leads to a $1^{\circ}$ increase in LC and a $2^{\circ}$ summarized decrease in DU and DT. The total sum of the four SDPRs remains $360^{\circ}$. Higher values of ER and LC decrease the value of DU and DT, where DU and DT collectively determine the "Power" angle. So, there is a relationship between the change in SDPRs and the angles in society's value triangle. Ideally, the value triangle is equilateral, balanced and each angle has $60^{\circ}$. A change in one of the vertices leads to a change in the other two. A decrease in "power" leads to a summarized increase in "freedom" and "money" angles. Above we said how deviations from the ideal measures of the SDPRs reflect changes in the ideal measures of value triangle. Table 8 formalizes this line of calculations.

Table 7: Correlation of SDPRs deviations from ideal values

\begin{tabular}{|c|l|l|l|l|l|l|}
\hline 1 & \multicolumn{1}{|c|}{2} & \multicolumn{1}{|c|}{3} & \multicolumn{1}{c|}{4} & \multicolumn{1}{c|}{5} & \multicolumn{1}{c|}{6} \\
\hline SDPR & $\begin{array}{l}\text { Ideal } \\
\text { value }\end{array}$ & $\begin{array}{l}\text { Limits } \\
\text { of value }\end{array}$ & $\begin{array}{l}\text { Interdependence } \\
\text { in deviation } \\
\text { from ER ideal } \\
\text { value change }\end{array}$ & $\begin{array}{l}\text { Interdependence } \\
\text { in deviation } \\
\text { from LC ideal } \\
\text { value change }\end{array}$ & $\begin{array}{l}\text { Interdependence } \\
\text { in deviation from } \\
\text { DU ideal value } \\
\text { change }\end{array}$ & $\begin{array}{l}\text { Interdependence } \\
\text { in deviation from } \\
\text { DT ideal value } \\
\text { change }\end{array}$ \\
\hline ER & $90^{\circ}$ & $\begin{array}{l}\text { from } 1^{\circ} \text { to } \\
357^{\circ}\end{array}$ & $\begin{array}{l}\text { Increase/ } \\
\text { decrease }\end{array}$ & - & $\begin{array}{l}\text { Decrease/ } \\
\text { increase }\end{array}$ & - \\
\hline LC & $90^{\circ}$ & $\begin{array}{l}\text { from } 1^{\circ} \text { to } \\
357^{\circ}\end{array}$ & $\begin{array}{l}\text { Increase/ } \\
\text { decrease }\end{array}$ & $\begin{array}{l}\text { Increase/ } \\
\text { decrease }\end{array}$ & $\begin{array}{l}\text { Decrease/ } \\
\text { increase }\end{array}$ & $\begin{array}{l}\text { Decrease/ } \\
\text { increase }\end{array}$ \\
\hline DU & $90^{\circ}$ & $\begin{array}{l}\text { from } 1^{\circ} \text { to } \\
357^{\circ}\end{array}$ & $\begin{array}{l}\text { Decrease/ } \\
\text { increase }\end{array}$ & $\begin{array}{l}\text { Decrease/ } \\
\text { increase }\end{array}$ & $\begin{array}{l}\text { Increase/ } \\
\text { decrease }\end{array}$ & Increase/decrease \\
\hline DT & $90^{\circ}$ & $\begin{array}{l}\text { from } 1^{\circ} \text { to } \\
357^{\circ}\end{array}$ & $\begin{array}{l}\text { Decrease/ } \\
\text { increase }\end{array}$ & $\begin{array}{l}\text { Decrease/ } \\
\text { increase }\end{array}$ & Increase/ decrease & $\begin{array}{l}\text { Increase/ } \\
\text { decrease }\end{array}$ \\
\hline Total & $360^{\circ}$ & & & & & \\
\hline
\end{tabular}

Source: the author

Table 8: Calculating the angles in value triangle using SDPRs measures

\begin{tabular}{|l|l|l|l|l|}
\hline \multicolumn{1}{|c|}{ SDPRs } & $\begin{array}{c}\text { Angles in value } \\
\text { triangle }\end{array}$ & \multicolumn{1}{|c|}{$\begin{array}{c}\text { Ideal } \\
\text { value }\end{array}$} & Values' limits & \multicolumn{1}{c|}{ Real value } \\
\hline$(\mathrm{DT}+\mathrm{DU})$ & Power & $60^{\circ}$ & $\begin{array}{l}\text { From } 0,5^{\circ} \\
\text { to } 177,5^{\circ}\end{array}$ & $(\mathrm{DT}+\mathrm{DU}) / 2$ \\
\hline$(\mathrm{ER}+\mathrm{LC})$ & Money & $60^{\circ}$ & $\begin{array}{l}\text { From } 0,5^{\circ} \\
\text { to } 177,5^{\circ}\end{array}$ & $\left(180^{\circ}-(\mathrm{DT}+\mathrm{DU}) / 2\right)^{*} \beta \%$ \\
\hline$(\mathrm{ER}+\mathrm{LC})$ & Freedom & $60^{\circ}$ & $\begin{array}{l}\text { From } 0,5^{\circ} \\
\text { to } 177,5^{\circ}\end{array}$ & $\left(180^{\circ}-(\mathrm{DT}+\mathrm{DU}) / 2\right)^{*} \alpha \%$ \\
\hline Total & & $180^{\circ}$ & & $180^{\circ}$ \\
\hline
\end{tabular}

Source: the author 
The hypothetical possibility, but still a possibility, that the "Liberty" and "Money" angles are equal is avoided by the adjustment done with $\alpha$ and $\beta$, the sum of which is $100 \%$. Thus, for example, if the "Power" angle shows a value of $62^{\circ}$, then the sum of the "Money" and "Freedom" will be corrected to $118^{\circ}$. That is, according to the rule for the sum of the angles of a triangle, the $2^{\circ}$ added to "Power" is summed by taking away from the angles "Liberty" and "Money," but perhaps not equally. If $\alpha=60 \%, \beta=40 \%$, then according to Table 8 , the angle "Liberty" will increase to $118^{\circ} * 60 \%=70.8^{\circ}$, and the angle "Money" will decrease to $47.2^{\circ}$. As a consequence the increase of "power" by $2^{\circ}$, in a society with prevailing attitudes towards freedom, will increase the "Freedom" angle to $70.8^{\circ}$ and decrease the "Money" angle to $47.2^{\circ}$. The total sum of the angles remains $180^{\circ}$.

Now we will analyze the participation of the different subsystems of society measured by their distance. Primarily the distances are the same. We will find their real values again by means of SDPRs' sizes. The participation of the societal subsystem, or the radius of its circle, is equal to the SDPR "entitlements rights". The larger this radius is, i.e. the larger the SDPR "entitlements rights" is, the larger its participation is. We measure the distance between the societal and the political subsystems with the SDPR "mistrust". Low values of this type of SDPR imply low dimension of the divergence of subsystem values and therefore low risk for the social system. Between the societal and political subsystems lie the economic, financial and technological subsystems. No specific mathematical formulation can be applied here because the symbiosis politic-economic-financetechnology needs additional research. Such an analysis should start with a consideration of subsystemic relations arising from the relations between: 1) the top five political powers - Russia, China, the US, Japan, the EU; 2) the top four in finance - WB, IMF, WTO, FED; 3) the top five in technology - Google, Amazon, Facebook, Apple, Microsoft; 4) top four in auditing - Price Waterhouse Cooper, Deloitte, KPMG, Ernst \& Young; 5) top three in rating business - Standard \& Poor's, Fitch, Moody's; 6) top three NGOs - Vatican, WHO, Amnesty International. This complication implies measuring only the participation of the societal subsystem and its distance from the political one. It is obvious that the less the distance between societal and political subsystem is, the less the distance between societal and other subsystems will be.

As already said, the SDPRIx measures political risk in society, which is directly related to the sustainability of the cultural and civilization model. According to T. Parsons (Figure 1), the cultural system is located above the social one. The distance between the two systems is the measure of the model's sustainability, because culture is a cumulated human activity covering all the dimensions - societal, economic, financial, political, technological, etc. Therefore, ideally, at a 
distance of 0 , we can say that there is a sustainability of the cultural-civilizational model, i.e. what is "produced" in society, based on society's law, is the civilization. Therefore, we measure the social-cultural systems distance by the difference between the SDPRs "distrust" and the "entitlements rights". The greater the gap in question, the more distant the cultural system would be from the social system, hence the more unsustainable the civilization model would be. There is also a hypothetical case where the difference is negative, i.e. the entitlements rights are more than the distrust. This situation means that the cultural model overlaps the political model, a hypothesis that never met in human history.

In summary, the distances between the subsystems measure their participation and will affect the outcome of the location of the value triangle in society or, more generally, the political risk to the social system. This will also reflect the sustainability of the cultural-civilizational model. Formally, the distances between subsystems and systems can be modeled as shown in Figure 5.

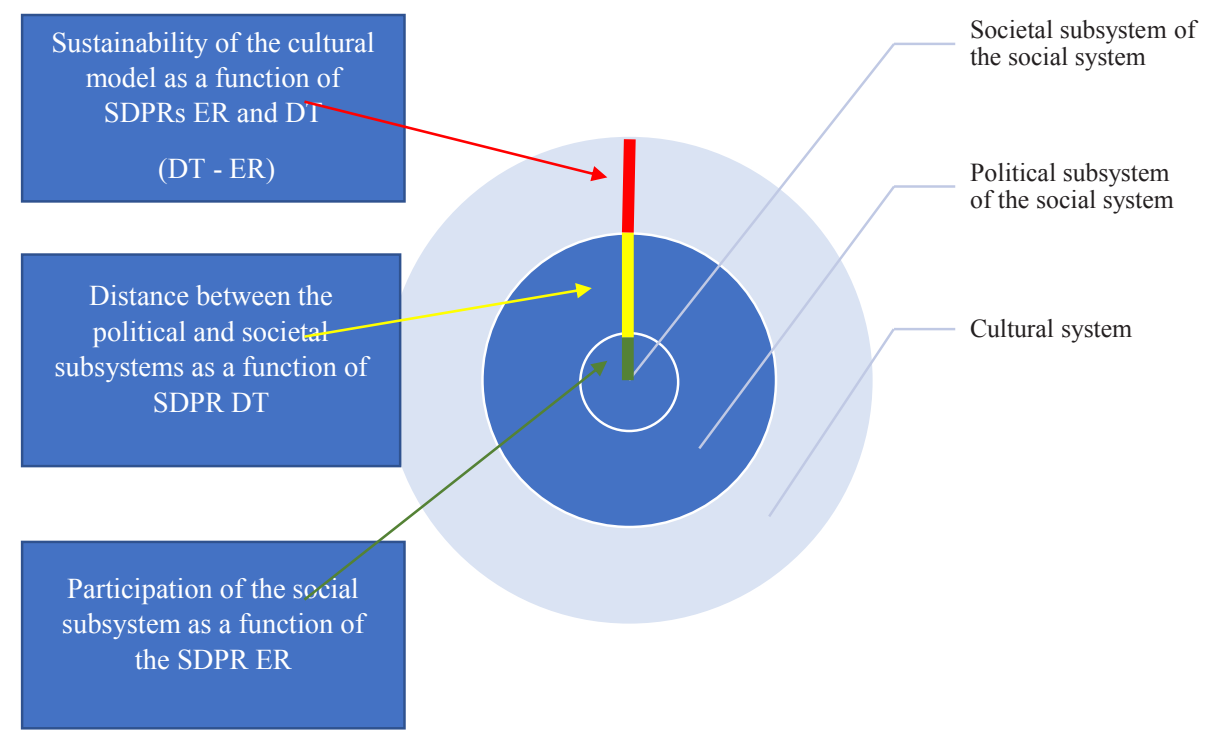

Source: the author

Figure 5: Participation/ distance of subsystems in society and SDPR's influence on the civilization-cultural model presented by the cultural system

The SDPRIx is geometric. According to the sizes of the angles of the value triangle, the distances of the subsystems and systems, a concrete real model of a certain situation is achieved. The distances of the subsystems position the triangle so that not all systems participate in the formation and experience of values. The adjacent arcs to the corners indicate how much a particular subsystem is involved 
in experiencing a particular value and lead to inferences about risk and conflict perspectives. The SDPRIx, if applied in reverse order, can be used to plan for political change, otherwise it shows the current risk for society.

The next figure presents as an example the value triangle of society in the context of global pandemic 2020.

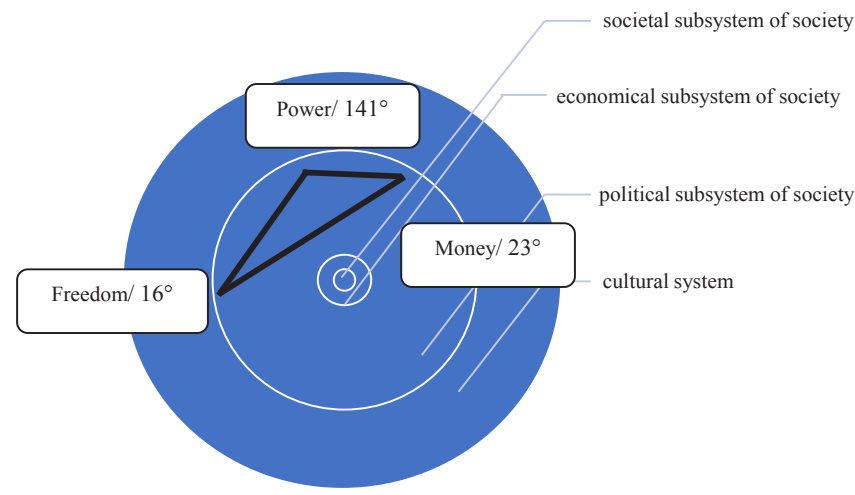

Source: Kodjabasheva (2021, p. 178)

Figure 6: The value triangle during the global pandemic situation 2020.

\section{Conclusion}

As a systemic risk political risk has social dimensions as well. They are the result of the value incommensurability of societal subsystems with other and can, and should, be measured. The impact of the SDPRs on social system risk is direct, and it influences the sustainability of the cultural-civilizational model, which is the commutative and emergent dimension of the actions and interactions of all subsystems in society.

In its anniversary report "Come on!", the Club of Rome concludes on the need for holism in science and a new Enlightenment, which is referred to as Enlightenment 2.0. It conceptualizes the phenomenon in a balance similar to the yin-yang balance familiar to us from Eastern philosophies. Their ideas aim at a achieving a balance of dichotomous pairs such as people and nature; short and long term; speed and stability; private and public; women and men; equality and reward; state and religion (f. Vaytszeker, Viykman, 2018, p. 120). This study holistically examines five theories - risk theory, political risk, systems, globalization and values to argue that political risk is a risk not only to the profit and investment plans of international business, but also to society as a whole. This impact is measured by the social dimensions of political risk - SDPRs. This 
study makes the case for the need to balance subsystems in society and systems in reality. The idea to aim at the subsystems' balance, albeit not a dichotomous one, comes from the scientifically proven nature, meaning and ubiquity of the system, where dichotomy is not a guiding principle but just an expression of the alternation of processes of integration and disintegration in the system. The systems' main principles are cumulativeness and emergentness: the wholeness is more than the sum, the single interactions are more than a dichotomy. Additionally, the current study presents the root cause of all human action - the value system, and gives it its well-deserved place as a major risk potential, coming from the drastic divergence between the value system and the artificial rational constructs such as the laws, which have value functions without being values. Society's value triangle presented here and the SDPRIx, which aims to calculate the political risk to the social system, expose the importance of the participation of the value-carrying societal subsystem in the lawmaking process to offset the exclusivity of the political subsystem to legislate.

A pivotal point, here, is the principle of isomorphism, the basis of the GST, which gives us a reason to think of the system's laws and principles as similar. That's why it seems logical that the absence of legislative exclusivity in the system in principle means also an absence of such in the social system. But there is a legislative exclusivity in the social system belonging to the political subsystem, and its lawmaking body presents $0.0003 \%{ }^{5}$ of the system. Thus, a major conclusion from what has been said so far is that there is a need to overcome the paradigm of democracy precisely in the part of suffrage in favour of broad participation of the societal subsystem in law-making. There is a need for a breakthrough in the paradigm of democracy, its institutional requisites, the formation of the market and the path of laws in society. The anchor points for this change could be: 1) the lawmaking principle to be laid on mutual abstinence through adequate participation of the societal subsystem; 2) the principle of mutual abstinence of authorities, needs to be brought to the subsystems of society; 3 ) broad participation of the societal subsystem in the lawmaking process; 4) not election but empowerment for representation; 5) election of an executive authority not the legislative one; 6) broaden participation of the societal subsystem by technological means.

It is also necessary to analyse the development of economic practices called "shared economy", "trust economy" and technological practices related to "open sources". They will also seek their analogue in the political subsystem, which will be a challenge for it and for society. In this sense, the technological-cultural-civilizational choice of humanity puts in opposition two important processes possible by technological means - a broad participation of the societal subsystem in the legislative process and

${ }^{5}$ Calculated as a percentage of the representative of national parliament to the number of people, therefore it is different percentage for each country. 
therefore mutual interdependence of the subsystems, on the one hand, and complete control over the societal and economic subsystems, on the other. The question of how this changes the value perceptions, political risk, and the social system is not only interesting, but also important for the future of humanity.

Let's conclude with the thought of R. Dahrendorf: "Life is about participation and meaningfulness, and for both citizenship and the well-being of the people is only a condition" (Dahrendorf, 1998, pp. 229, 241). The concept for the social dimensions of political risk and the SDPRIx are in fact an attempt to place values and meaningfulness as the primary cause and the citizenship and economic growth as a consequence.

\section{Acknowledgment}

This publication is carried out within the framework of a research project funded by the UNWE R\&D F und, with reference number NI-18/2020, entitled: "The Kovid-19 pandemic as a political risk: analysis and impact assessment"

\section{References}

Бауман, 3. (2013). Глобализацията. Последиците за човека, Книгоиздателска къща „Труд“, София. (Bauman, Z., 2013. Globalizaciyata. Posleditsi za choveka, Knigoizdatelska kashta Trud, Sofia).

Бек, У. (2001). Световното рисково общество, Обсидиан, София. (Beck, U., 2001, Svetovnoto riskovo obshtestvo, Obsidian, Sofia).

Вебер, М. (1998). Политиката като призвание; Науката като призвание, „Рива ЕООД“, София. (Weber, М., 1998, Politikata kato prizvanie; Naukata kato prizvanie, Riva EOOD, Sofia).

ф. Вайцзекер, Е. У., Вийкман, А. (2018). Хайде! Капитализъм, късогледство, население и разрушаване на планетата, Доклад на Римския Клуб, „Книжен тигър“, София. (f. Vaytszeker, E. U., Viykman, А., 2018, Hayde! Kapitalizam, kasogledstvo, naselenie i razrushavane na planetata, Doklad na Rimskia Klub, „Knizhen tigar“, Sofia).

Дарендорф, Р. (1998). Модерният социален конфликт. Есе за политиката и свободата, ИК „Златорог“, София. (Dahrendorf, R., 1998, Moderniyat sotsialen conflict. Ese za politikata I svobodata, IK Zlatorog, Sofia).

Дочев, Д., Николаев, Р., Милкова, Т. (2007). Теория на риска. Рьководство, „Наука и икономика“, Варна. (Dochev, D., Nikolaev, R., Milkova, T., 2007, Teoriya na riska. Rakovodstvo, Nauka i Ikonomika, Varna).

Дочев, Д., Славов, Здр., Петков, Йо., Генчев, Ан. (2014). От теория на игрите до теория на драмите, (Dochev, D., Slavov, Zdr., Petkov, Jo., Genchev, An., 2014, Ot teoriya na igrite do teoriya na dramata), e-journal of VFU, issue 7, available at: https://ejournal.vfu.bg/en/pdfs/GameSMB2013_d1.pdf 
Social Dimensions of Political Risk - SDPR: Concept and Index for Risk Impact on Society

Дюверже, М. (1999). Социология на политиката, „Кама“, София. (Duverger, M., 1999, Sotsiologiya na politikata, Kama, Sofia).

Кант, И. (1977). Към вечния мир, Издателство БАН, София. (Kant, I., 1977, Kam vechniya mir, Izdatelstvo BAN, Sofia).

Коджабашева, Р. (2021) Политическият риск за обществото, ИК УНСС, София. (Kodjabasheva, R., 2021, Politicheskiqt risk za obshtestvoto, IK UNSS, Sofia)

Луман, Н. (2008). Въведение в системната теория, „Социооптика“, София. (Luhman, N., 2008, Vavedenie v sistemnata teoriya, Sotsiooptika, Sofia).

Парсънз, Т. (2005). Еволюция на обществата, „Социооптика“, София. (Parsons, T., 2005, Evolutsia na obshtestvoto, Sotsiooptika, Sofia).

Парсьнз, Т. (1998). Системма Современных обществ, „Аспект Пресс“, Москва. (Parsons, T., 1998, Sistema sovremennih obshtesv, Aspect Press, Moskva).

Попър, К. (1993). Някои проблеми на новите демокрации, София: Калъс и УИ „Св. Климент Охридски“, 1993. (Popper, К., 1993, Nyakoi problemi na novite demokratsii, Sofia: Kalas i UI “Sv. Kliment Oridski”).

Симеонова, Е. (2013). Политическият риск. Анализ, оценка, управление, УИ „Св. Климент Охридски“, София. (Simeonova, E., 2013, Politicheskiyat risk. Analiz, otsenka, upravlenie, UI “Sv. Kliment Ohridski”, Sofia).

Фотев, Г. (2012). Сфери на ценностите, НБУ, София. (Fotev, G., 2012, Sferi na tsennostite, NBU, Sofia).

Христов, П. (2010). Метатеория на риска. Парадигми и подходи, „Албатрос“, София. (Hristov, P., 2010, Metateoriya na riska. Paradigmi i podhodi, Albatros, Sofia).

Хънтигтън, С. (1999). Сблъсък на цивилизациите и преобразуването на световния ред, „Обсидиан“, София. (Hantington, S., 1999, Sblasak na tsivilizatsiite I preobrazuvane na svetovniya red, Obsidian, Sofia).

Bernstein, P. L. (1996). Against the Gods. The remarkable story of risk, New York: John Willey and Sons, Inc.

Bertalanffy, L. von. (1973). General System Theory, New York: George Brazilier, Inc.

Bremmer, I. (2006). The J Curve: A New Way to Understand Why Nations Rise and Fall, New York: New York: Simon Schuster.

Easton, D. (1966). Varieties of political Theory, Englewood Cliffs, N. J.: Prentice - Hall, Inc.

Kahneman, D., Twerski, A. (1984). Choices, values and frames, American Psychologist, pp. 341-350.

Copeland, A.H. (1945). Book review: Theory of games and economic behavior by John von Neumann and Oskar Morgenstern, Bulletin of the American Mathematical Society, 51(07): pp. 498-504, doi:10.1090/s0002-9904-1945-08391-8. 